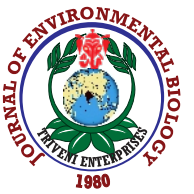

\title{
Relative incidence of aphid (Lipaphis erysimi) and Alternaria blight on mustard in sub-mountainous region of Punjab
}

\section{Rakesh Kumar Sharma* and K.K. Sharma}

Dr. D.R. Bhumbla Regional Research Station (Punjab Agricultural University, Ludhiana), Ballowal Saunkhri, Tehsil Balachaur, Shahid Bhagat Singh Nagar- 144521 , India

*Corresponding Author Email : rksharma@pau.edu

\begin{tabular}{lll}
\hline Received: 24.06 .2020 & Revised: 06.11.2020 & Accepted: 16.12 .2020 \\
\hline
\end{tabular}

\section{Abstract}

Aim: To study the relative incidence of mustard aphid and Alternaria blight on different rapeseed-mustard varieties to assess their resistant or tolerant and most suitable variety for sub-mountainous area of Punjab.

Methodology: The experiment was conducted on four mustard varieties (RLM-619, PBR-97, PBR-357 and Giriraj) with five replications in randomized block design during two crop seasons, i.e. Rabi 2018-19 and 2019-20 under sub-mountainous areas of Punjab. Aphid population was recorded at weekly interval. Disease severity was calculated using 0-5 rating scale and per cent disease intensity was calculated.

Results: RLM-619 variety exhibited the lowest aphid infestation (7.92 and $8.96 \%)$ and minimum per cent disease intensity (28.0 and $33.33 \%$ ) on leaves and siliqua (33.33 and $38.33 \%$ ) which also gave highest yield $\left(739.33 \mathrm{~kg} \mathrm{acre}^{-1}\right.$ and $\left.735.67 \mathrm{~kg} \mathrm{acre}^{-1}\right)$ during the year 2018-19 and 2019-20. The lowest seed yield (487.67 $\mathrm{kg}$ acre $^{-1}$ and $\left.480.67 \mathrm{~kg} \mathrm{acre}^{-1}\right)$ was recorded in variety Giriraj, which was found susceptible to aphid infestation and Alternaria blight.

Interpretation: RLM-619 exhibited tolerance against aphid and Alternaria blight, hence, this variety may be used as a key component under integrated pest and disease management in sub-mountainous area of Punjab in future.

Key words: Alternaria blight, Aphid, Lipaphis erysimi, Mustard

Area specific research to study pest and disease incidence on four mustard varieties (RLM 619, PBR97, PBR 357 \& Giriaj)

Record weekly data on aphid population on central shoot (top $10 \mathrm{~cm}$ ) of each randomly selected plant starting with the appearance of the aphids till the harvesting of the crop

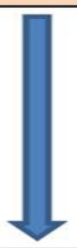

Data was analyzed to interpretate for the occurrence of aphid infestation and Alternaria blight

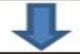

Conclusion was made regarding variety suitable for the sub-mountainous region on the basis of least occurrence of aphid infestation and Alternaria blight on a particular variety
Record the data on disease serverity on leaves ( 90 days after sowing) by using

$0-5$ rating scale while on siliquae (105 days after sowing) with 0-4 rating scale on ten randomly selected plants

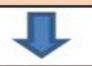

Percent Disease Intensity were calculated both on leaves and siliquae by using the formulae

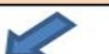




\section{Introduction}

Rapeseed-mustard (Brassica campestris L.) belongs to family Cruciferae is the second most important oilseed crop in India and constitutes the major source of edible oil for human consumption and feed for animals. In general, toria (Brassica rapa), gobhi sarson (Brassica napus var. napus) and taramira (Eruca sativa) are categorised as rapeseed, while raya (Brassica juncea) and African sarson (Brassica nigra) are considered as mustard. In India, the area under rapeseed-mustard cultivation is estimated to be 6.7 million ha with a production and productivity of 7.90 million tonnes and $1188 \mathrm{~kg} \mathrm{ha}^{-1}$ (GOI, 2014), respectively. In Punjab rapeseed and mustard is being cultivated on 30.5 thousand ha land with a production of 46.5 thousand tonnes and productivity of 15.24 quintals ha ${ }^{-1}$ during 2018-19. Toria, gobhi sarson and African sarson are sown excusively under irrigated conditions whereas raya can be grown under both irrigated and rainfed conditions (PAU, 2020). Oilseed crops play an important role in the economy of India.

Rapeseed-mustard crop is vulnerable to a wide variety of insect pests and diseases from sowing till harvest which results in low yields. Among the insect-pests, mustard aphid Lipaphis erysimi Kalt (Aphididae: Homoptera) is the most devastating pest in Punjab causing serious problem from flowering till harvest of mustard crop. Heavy seed yield losses up to 9 to $96 \%$ has been reported by due to aphid infestation in different agroclimatic conditions of India (Gautam et al., 2019). The aphid attacks the crop generally during December and continues till April. It by severe damages the plants as both nymph and adult of the aphid suck sap from leaves, stems and flowers and tender pods of the plant. Aphid infestation during early stages result in weak and stunted plants (Ansari et al., 2007; Parmar et al., 2007; Mamun et al., 2010; Sahu et al., 2017). Infestation of inflorescence leads to withering of flowers which hinders pod formation (Kumar and Sangha, 2013; Kumar and Singh, 2015; Kumar et al., 2015; Gautam et al., 2019). Alternaria blight is prominent in all rapeseed - mustard growing areas of India, including Rajasthan, Punjab, Haryana and Uttar Pradesh (Sangwan et al., 2002) and in other countries (Abdalla M. El-Alwany, 2015; Singh et al., 2017).

The average yield loss in rapeseed-mustard due to Alternaria blight was reported at 10.0 to 70.0 per cent in different parts of India which depends on severity of the disease (Shrestha et al., 2005; Chattopadhyay, 2008; Meena et al., 2010; Khan, 2011; Meena et al., 2011, Saharan et al., 2016) and Annual yield losses of 10.0 to $40.0 \%$ were also estimated by Mondal (2008) from northern part of West Bengal caused by Alternaria brassicae (Berk) Sacc. Since the use of resistant or tolerant varieties are considered as an important strategy of integrated management of pests and diseases, considering the economic value of the crop and extensive damage caused by mustard aphid and Alternaria blight disease, the present study was conducted to assess the relative susceptibility of different rapeseed-mustard varieties against pest and diseases in submountainous area of Punjab.

\section{Materials and Methods}

Field experiments were conducted at Dr D.R. Bhumbla Regional Research Station Ballowal Saunkhri (Punjab Agricultural University) during Rabi seasons of two consecutive 2018-19 and 2019-20, i.e., from November 2018 to April 2019 and November 2019 to April 2020 to observe the incidence of mustard aphid and Alternaria blight on different varieties of raya. Four mustard (raya) varieties, Giriraj, PBR 97, PBR 357 and RLM 619 were evaluated under sub-mountainous regions of Punjab. The experiment was laid out in RBD with five replications and a plot size of $10 \times 5 \mathrm{~m}$. The agronomical operations were followed as per the package of practices for Rabi crops by PAU, Ludhiana. No plant protection measures were taken throughout the crop season. Observations on aphid incidence were recorded at weekly intervals starting from the initial appearance till harvesting of the crop. Alternaria blight initially appears on older leaves which progresses to younger leaves, stem and branches.

Observation on mustard aphid population: The aphid population was recorded on ten randomly selected plants, starting from the week of first appearance of aphids till harvest of the crop at weekly intervals confining only to top $10 \mathrm{~cm}$ of the central shoot on each plant.

Assessment of disease severity: Ten plants were randomly selected and tagged for taking observations. Ten leaves and ten siliqua were taken from these plants for scoring disease severity. The overall scoring of disease on leaves was done at $0-5$ (where 0 $=$ no infection, $1=\leq 1-10 \%$ leaf area infected, $2=11-25 \%$ leaf area infected, $3=26-50 \%$ leaf area infected, $4=51-75 \%$ leaf area infected $5=\geq$ leaf area infected) and 0-4 rating scale (where $0=$ no infection, $1=$ minute, superficial lesions on the pods, $2=$ one to two deep lesions/pod, 3 = three to five deep lesions $/$ pod, $4=$ more than five deep lesions/pod) for pod infection as proposed by Conn et al. (1990) and Saharan (1992), respectively for the assessment of Alternaria blight disease of rapeseed and mustard. The disease severity of Alternaria blight was recorded on $90^{\text {th }}$ day after sowing (DAS) on leaves and $105^{\text {th }}$ DAS on siliqua. The percent disease index was calculated. The harvested crop of each plot was separately and bundled, properly tagged. Enough care was taken at harvesting, threshing and also cleaning mustard. The seeds were cleaned and finally the weight was measured and converted into per acre yield.

Statistical analysis: The data obtained from experimental field were transformed into square root and subjected to statistical analysis of variance (ANOVA) from RBD and yield of different varieties were converted into $\mathrm{kg}_{\text {acre }}{ }^{-1}$. All data on aphid and disease were analysed using SPSS software for proper interpretation.

\section{Results and Discussion}

The incidence of mustard aphid Lipaphis erysimi on different varieties was studied for two seasons. During the first 
year (2018-19) the initial appearance of aphid was recorded on $2^{\text {nd }}$ standard meteorological week (SMW) $2^{\text {nd }}$ week of January on two varieties PBR 357 and Giriraj with 1.33 and 2.0 mean aphids per $10 \mathrm{~cm}$ central shoot, respectively, however, there was no aphid population recorded on varieties PBR 97 and RLM 619 (Table 1). The aphid population increased after $2^{\text {nd }}$ SMW and attained the peak on all mustard varieties at the same time, i.e., $9^{\text {th }}$ SMW ( $4^{\text {rd }}$ week of February) during 2018-19 (Table 1). During the peak period, least aphid population was observed on variety RLM 619 (22.78 aphids), followed by PBR 97 (27.14) and both were at par to each other. However, these varieties significantly differed from PBR 357 (30.22 aphids) and Giriraj (33.18 aphids). The aphid population after reaching peak period started to decline and finally reached to negligible at maturity of the crop (during $14^{\text {th }}$ SMW). In the fourth week of March, the inflorescence of RLM 619 variety were least infested by aphid (0.44), followed by PBR 97, PBR 357 and Giriraj showing 0.68, 1.22 and 1.84 aphids per inflorescence, respectively.

During 2019-20 aphid population appeared in all varieties during $3^{\text {rd }}$ week of January. In third week, the RLM 619 was least preferred variety, showing only 1.06 aphids per inflorescence followed by PBR 97, PBR 357 and Giriraj with 1.70, 3.46 and 3.82 aphids, respectively (Table 2). Thereafter, the aphid population continued to increase on all the mustard varieties and maximum population was recorded during $10^{\text {th }} \mathrm{SMW}$ ( $1^{\text {st }}$ week of March). In the $1^{\text {st }}$ week of March, the variety RLM 619 was least preferred by the aphid with 25.78 aphids, which was at par to PBR 97 with 29.18 aphids per $10 \mathrm{~cm}$ central shoot. PBR 357 was intermediate with 34.72 aphids, while Giriraj was found most susceptible variety showing 36.44 aphids and this was significantly different to each other. Thereafter, the population tend to decrease on all the four varieties and was negligible during last week of March. The least number of aphids 0.88 per inflorescence was present in RLM 619, followed by PBR 97, PBR 357 and Giriraj showing 1.92, 2.46 and 2.98 aphids per inflorescence.

During 2018-19 and 2019-20, the average means of incidence showed that the variety RLM 619 recorded the least incidence (7.92 and 8.96 aphids per inflorescence) (Table 1). Thus, this variety was least preferred by aphid, while variety PBR 97 showed intermediate effect of preference with mean aphid population 10.05 and 11.12 aphids per inflorescence during 201819 and 2019-20. However, on the basis of incidence variety, PBR 357 (12.43 and 14.32 aphids) and Giriraj (13.99 and 15.64 aphids) was found most susceptible during 2018-19 and 2019-20. Variability of tolerance recorded in mustard varieties was in the following order: RLM-619 <PBR $97<$ PBR 357<Giriraj. No variety was found to be completely resistant to $L$. erysimi, though they differed in their susceptibility level. The perusal of mean data indicated that during 2018-19, yield was maximum in RLM 619 (739.33 kg acre-1), followed by PBR 97 (689.67 kg acre $\left.{ }^{-1}\right)$. These two varieties were statistically at par with each other. However, the minimum mean yield was obtained in PBR 357 ( $\left.674 \mathrm{~kg} \mathrm{acre}^{-1}\right)$ followed by Giriraj (487.67 kg acre $\left.{ }^{-1}\right)$ which were statistically different from each other (Table 1). Similarily, during 2019-20 yield was recorded maximum in RLM 619 (735.67 kg acre $\left.{ }^{-1}\right)$ followed by PBR 97 ( $683 \mathrm{~kg}$ acre $\left.^{-1}\right)$. These two varieties were statistically at par with each other. However, minimum mean yield was obtained in PBR 357 (667.67 kg acre-1) followed by Giriraj (480.67 kg acre$\left.{ }^{1}\right)$, which were statistically different from each other (Table 2 ). The influence of various environmental factors on the population of aphids indicated a gradual increase from January in response to increase in temperature $\left(16-20^{\circ} \mathrm{C}\right)$, as a result maximum infestation of aphids were encountered during February and March on mustard crop, particularly on flower portion (Table 1). On the other hand, in the last week of March, population of aphids drastically decreased due to gradual increase in temperature (25$26^{\circ} \mathrm{C}$ ) and lack of food availability as flower are converted in to pods. Egg mortality of aphids started to increase with increasing temperature $\left(27-36^{\circ} \mathrm{C}\right)$ as they were not able to maintain moisture inside the egg as result, the embryo desiccated and shrinked. While mature aphid did not get sufficient food in absence of flower and, therefore, were unable to sustain their life and proliferated.

The results of present studies are in line with Dwivedi et al. (2019) who reported that aphid incidence begin to appear in $3^{\text {rd }}$ week of January. These findings are in conformity with the observations of Saljoqi et al. (2011) who reported the mustard aphid population was maximum from mid February to mid March when the crop was at the flowering stage and there is ample food for its multiplication and survival that resulted in increase in its population (Dwivedi et al., 2019; Singh et al., 2012; Singh and Lal, 2012; and Saljoqi, 2011). Furthermore, these studies are in line with Ali and Rizwi (2011) and Dwivedi et al. (2019) who reported that RLM 619 was moderately tolerant against aphid. On the basis of $0-5$ rating scale, disease severity of Alternaria blight on leaves was recorded 90 days after sowing which ranged from $11.33 \%$ to $30.67 \%$ during $2018-19$ (Table 2) whereas, it was $16.67 \%$ to $36.00 \%$ in $2019-20$. Minimum disease severity (11.33\%) on leaves was recorded in RLM 619 during 201819 (Table 2) and 2019-20 (16.67\%), followed by PBR 97 (18.67 and $23.33 \%$ ) for the respective years (Table 2). Per cent disease intensity on leaves during 2018-19 ranged from $28.00 \%$ to $58.67 \%$, while it was $33.33 \%$ to $60.00 \%$ in $2019-20$. The minimum percent disease intensity was recorded in RLM 619 (28.00\% and 33.33\%) during 2018-19 and 2019-20, respectively (Table 2).

Similar results were obtained for Alternaria blight when siliqua samples were examined 105 DAS for percent disease intensity. On siliqua, it varied from $33.33 \%$ to $66.67 \%$ on four varieties in $2018-19$ whereas it ranged from $38.33 \%$ to $68.33 \%$ during 2019-20. The minimum percent disease intensity $(33.33$ and $38.33 \%$ ) on siliqua was recorded in RLM 619 whereas Giriraj showed maximum (66.67 and 68.33\%) percent disease intensity during experimental years (Table 2). Severity of disease on leaves and percent disease intensity on siliqua was at par for treatments PBR 97 and PBR 357 during both years 2018-19 and 2019-20. Moreover, RLM 619 and PBR 97 were at par for during 2018-19 when PDI on siliqua is concerned. The results revealed that disease severity on leaves of RLM 619, PBR 97 and PBR 357 ranged from $11-22 \%$ (Table 2) and 16-24\% during 2018-19 and 


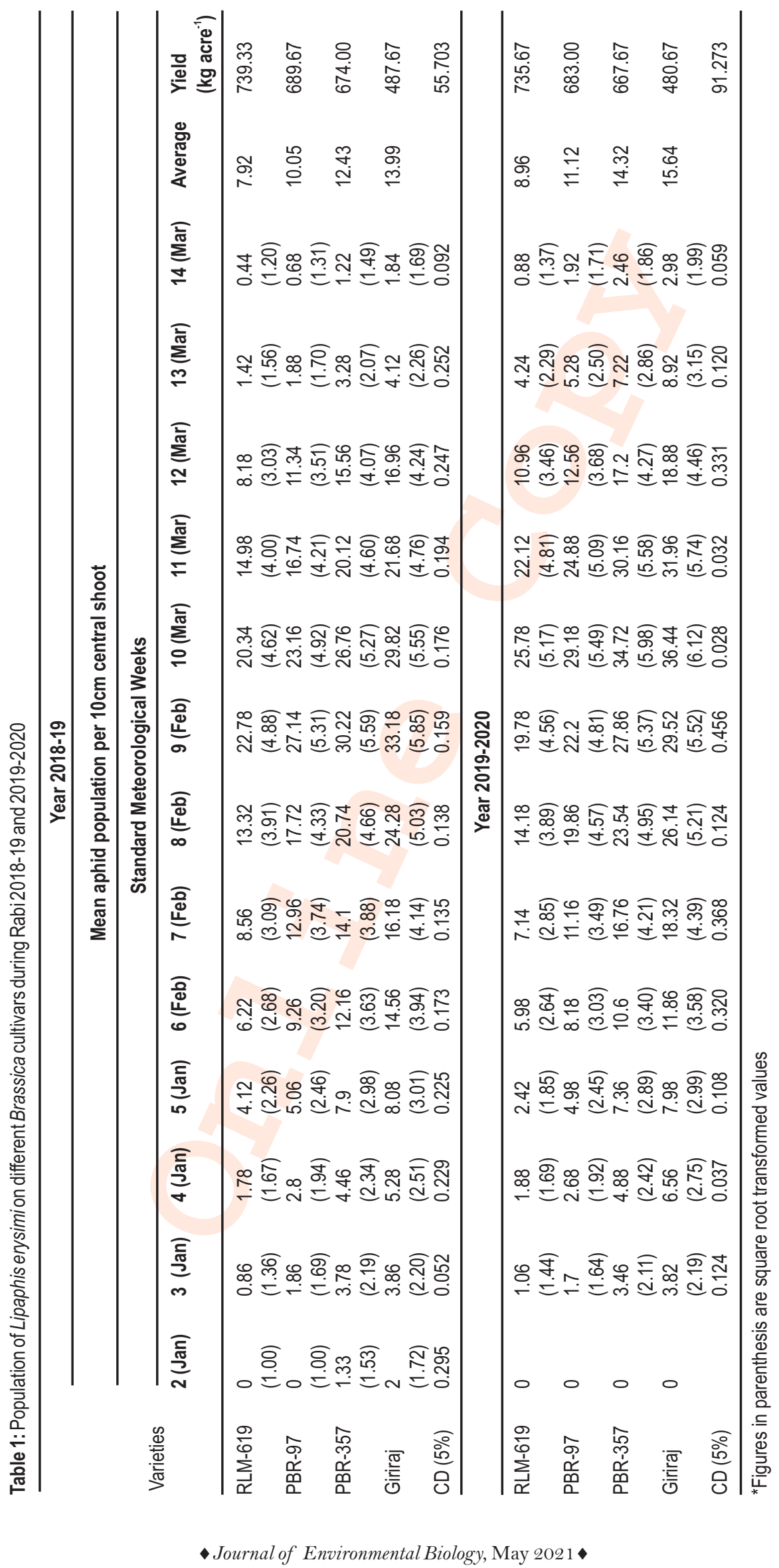


Table 2: Disease severity and per cent disease incidence in different Brassica cultivars against Alternaria blight during Rabi 2018-19 and 2019-2020

\begin{tabular}{lllll}
\hline \multirow{2}{*}{ Varieties } & \multicolumn{2}{l}{ Observation on leaves 90 DAS } & Observation on siliqua 105 DAS & \multirow{2}{*}{ Yield (kg acre-1) $^{-1}$} \\
\cline { 2 - 4 } & Disease severity (\%) & PDI (\%) & PDI (\%) & 737.67 \\
\hline RLM-619 & 11.33 & 28.00 & 33.33 & 684.00 \\
PBR-97 & 18.67 & 37.33 & 40.00 & 667.67 \\
PBR-357 & 22.00 & 41.33 & 43.33 & 490.67 \\
Giriraj & 30.67 & 58.67 & 66.67 & 55.703 \\
CD (5\%) & 4.465 & 6.512 & 7.590 & 737.67 \\
\hline & & Year 2019-2020 & 684.00 \\
\hline RLM-619 & 16.67 & 33.33 & 38.33 & 667.67 \\
PBR-97 & 23.33 & 44.00 & 48.33 & 490.67 \\
PBR-357 & 24.00 & 46.67 & 51.67 & 91.273 \\
Giriraj & 36.00 & 60.00 & 68.33 & 6.574 \\
CD $(5 \%)$ & 4.943 & 4.503 & & \\
\hline
\end{tabular}

2019-20, respectively. RLM 619 exhibited higher tolerance against disease as compared to others varieties. The maximum disease severity (30.67 and 36.00\%) and percent disease intensity (58.67\% and $60.00 \%$ ) on leaves were recorded (Table 2) on Giriraj during respective years which showed moderately susceptible reaction as per rating scale. The studies were conducted by various researchers on varietal performance of rapeseed-mustard using 0-5 rating scale to assess severity of Alternaria blight where none of the variety was found completely resistant though some of them were found moderately resistant (Ansari and Lal, 2008; Yadav et al., 2014; Sandhu et al., 2016; Gupta et al., 2017; Jain and Sandhu, 2019; Sharma and Kumar, 2020). In an another study to screen forty two genotypes of rapeseed-mustard against Alternaria blight, genotypes UDN-1129, UDN-11-36 and UDN-11-10 were found moderately resistant whereas UDN-11-05 exhibited resistance (Singh et al., 2014). In a study conducted by Sohi et al. (2020), more or less similar value of percent disease intensity (45.39\%) for Alternaria blight on PBR-97 was recorded (Sohi et al., 2020) whereas it was $47.00 \%$ on Giriraj (Dhaliwal and Singh, 2020) in November sown crop.

This study concludes that RLM 619 may be used for integrated pest and disease management as it was found moderately resistant to Alternaria blight and less susceptible to aphid attack which gave higher yield as compared to other varieties.

\section{Acknowledgment}

The authors are thankful to the Director, RRS Ballowal Saunkhri for providing the required facilities and manpower during research work.

\section{Add-on Information}

Authors' contribution: Rakesh Kumar Sharma and K.K. Sharma: Designing of experiment, data collection, analysis of data and interpretation.
Research content: The research content of manuscript is original and has not been published elsewhere.

\section{Ethical approval: Not applicable}

Conflict of interest: The authors declare that there is no conflict of interest.

Data from other sources: Not applicable

Consent to publish: All authors agree to publish the paper in Journal of Environmental Biology.

\section{References}

Abdalla, M. El-Alwany: Plant pathogenic Alternaria species in Libya. OpenAccess Library J., 02, 1-8 (2015).

Ali, A. and P.Q. Rizvi: Screening of different cultivars of rapeseedmustard against mustard aphid, Lipaphis erysimi, Kaltenbach. with respect to sowing dates. Asian J. Plant Scie., 10, 383-392 (2011).

Ansari, M.S., H. Barkat and N.A. Qazi: Influence of abiotic environment on the population dynamics of mustard aphid, Lipaphis erysimi (Kalt.) on Brassica germplasm. J. Biol. Sci., 7, 993-996 (2007).

Ansari, Z.A. and M.N. Lal: Reaction of Brassica genotypes to mustard aphid, Lipaphis erysimi (Kalt.) infestation. J. Prog. Agric., 8, 17-18 (2008).

Chattopadhyay, C.: Management of diseases of rapeseed-mustard with special reference to Indian conditions. In: Sustainable Production of Oilseeds: Rapeseed Mustard Technology, (Eds.: A. Kumar, J.S. Chauhan and C. Chattopadhyay). Agrotech. Publ. Acad., pp. 364388 (2008).

Conn, K.L., J.P. Tewari and R.P. Awasthi: A disease assessment key for Alternaria black spot in rapeseed and mustard. Canadian Plant Disease Survey, 70, 19-22 (1990).

Dhaliwal R.S. and B. Singh: Effect of weather parameters and date of sowing on intensity of Alternaria blight of rapeseed mustard. Indian Phytopath., 73, 89-95 (2020).

Dwivedi, S., R. Singh and R. Pragnabharathi: The screening of mustard varieties resistance against mustard aphid Lipaphis erysimi Kalt. 
Plant Cell Biotechno. Molec. Biol., 20, 397-408 (2019).

Gautam, M.P., S.N. Singh, P. Kumar, S.K. Yadav, D.P. Singh and M.K. Pandey: Mustard aphid, Lipaphis erysimi (Kalt) (Hemiptera: Aphididae): Areview. Pharma. Inn. J., 8, 90-95 (2019).

GOI: Agricultural statistics at a glance. Agriculture Statistics Division, Department of Agriculture \& Cooperative, Ministry of Agriculture, Government of India, New Delhi, p. 111-112 (2014).

Gupta, S., V.B. Singh, A.K. Singh, S.K. Rai, S.K. Singh and M.C. Dwivedi: Prevalence, incidence and management of Alternaria blight of rape-seed and mustard (Brassica juncea $\mathrm{L}$ ) through resistance and integrated approach. Int. J. Curr. Microbiol. App. Sci., 6, 27302741 (2017).

Jain, G. and S.K. Sandhu: Alternaria blight severity as influenced by meteorological parameters in mustard cultivars. Agric. Res. J., 56, 459-464 (2019).

Khan, M.M.: Alternaria blight of mustard a real farmer headache. Lap Lambert Academic Publishing, Germany, pp. 100 (2011).

Kumar, G.D.S., P. Duraimurugan, A.K. Sharma, D. Singh, S.D. Billore and N.K. Jain: Handbook on technologies for oilseeds production technologies for Rajasthan. ICAR-Directorate of Oilseed Research, Hyderabad, pp. 108 (2015).

Kumar, S. and M.K. Sangha: Biochemical mechanism of resistance in some Brassica genotypes against Lipaphis erysimi (Kaltenbach) (Homoptera: Aphididae). Vegetos, 2, 387-395 (2013).

Kumar, S. and Y.P. Singh: Insect-pests. In: Brassica Oilseeds Breeding and Management. (Eds: Kumar, A., S.S. Banga, P.D. Meena and P.R. Kumar). CABI Publishing, Wallingford, UK, pp. 193-232 (2015).

Mamun, M.S.A., M.H. Ali, M.M. Ferdous, M.A. Rahman and M.A. Hossain: Assessment of several mustard varieties resistance to mustard aphid, Lipaphis erysimi (Kalt.). J. Soil Nat., 4, 34-38 (2010).

Meena, P.D., R.P. Awasthi, S. Godika, J.C. Gupta, A. Kumar, P.S. Sandhu, P. Sharma, P.K. Rai, Y.P. Singh, A.S. Rathi, R. Prasad, D. Rai and S.J. Kolte: Eco-friendly approaches managing major diseases of Indian mustard. World Appl. Sci. J., 12, 1192-1195 (2011).

Meena, P.D., R.P. Awasthi, C. Chattopadhyay, S.J. Kolte and A. Kumar: Alternaria blight: A chronic disease in rapeseed-mustard. $\mathrm{J}$. Oilseed Brassica, 1, 1-11 (2010).

Mondal, G.: Evaluation of variety against Alternaria blight and Sclerotinia rot disease of rapeseed-mustard for old alluvial zone of the Northern part of West Bengal. Environ Ecol., 26, 2189-2191 (2008).

Parmar, G.M., M.N. Kapadiia, N.B. Jadav and V.J. Zizala: Avoidable losses due to Lipaphis erysimi (Kalt.) in mustard. Asian J. Biosci., 2,73-75(2007).

PAU: Package of practices for crops of Punjab-Rabi 2020-21. Directorate of Extension Education. Punjab Agricultural University, Ludhiana, p. 45-57 (2020).
Saharan, G.S., N. Mehta and P.D. Meena: Alternaria disease of Crucifers: Biology, Ecology and Management, Springer Verlag 2016, DOI: 10.1007/978-981-10-1021-8.2 (2016)

Saharan, G.S.: Management of rapeseed and mustard diseases. In: Advances in Oilseeds Research (Eds.: D. Kumar and M. Rai), Scientific Publishers, Jodhpur, India. 1, pp. 152-188 (1992).

Sahu, V., R.R. Yadav , R.P. Singh and P.K. Bareliya: Seasonal incidence of mustard aphid, Lipaphis erysimi in Jhansi during rabi crop season. PlantArchi., 17, 1505-1507 (2017).

Saljogi, A.R., R. Zada, I.A. Khan, I. Munir, Sadur-Rehman and H.J.A. Khan: Population trend of canola aphid, Lipaphis erysimi (Kalt.) (Homoptera: Aphididae) and its associated natural enemies in different Brassica lines along with the effect of gamma radiation on their population. World Acad. Sci. Engin. Tech., 73,187-194 (2011).

Sandhu, G.S., B.S. Sandhu and N.S. Dhaliwal: Field evaluation of different rapeseed mustard genotypes under semi-arid conditions of Punjab. Int. J. agric. Sci., 12, 42-46 (2016).

Sangwan, M.S., N. Mehta and S.K. Gandhi: Some pathological studies on Alternaria raphani causing leaf and siliqua blight of radish. $J$ Mycol. PI. Pathol., 32, 125-126 (2002).

Sharma, K.K. and V. Kumar: Varietal performance of taramira (Eruca sativa Mill.) against Alternaria blight in sub-mountainous Punjab. Agric. Res. J., 57, 430-432 (2020).

Shrestha, K.S., L. Munk and S.B. Mathur: Role of weather on Alternaria leaf blight disease and its effect on yield and yield components of mustard. NepalAgric. Res. J., 6, 62-72 (2005).

Singh, A.K. and M.N. Lal: Population dynamics of mustard aphid, Lipaphis erysimi (Kalt.) on mustard in relation to weather parameters. Asian J. Bio. Sci., 7, 216-218 (2012).

Singh, D., R. Prasad and B. Bairwa: Screening of brassica germplasm and breeding material against Altenaria brassicae causing alternaria blight under artificial condition. J. Pure Appl. Microbiol., 8, 4997-5001 (2014).

Singh, H.K., R.B. Singh, P. Kumar, M. Singh, J.K. Yadav, P.K. Singh, M.P. Chauhan, R.C. Shakywar, K.N. Maurya, B. Shainy Priyanka, T. Srivastava, S.K. Yadav and M.K. Maurya: Alternaria blight of rapeseed-mustard-A Review. J. Environ. Biol., 38, 1405-1420 (2017).

Singh, M.P., N. Madhushudan and K.I. Singh: Management of mustard aphid, Lipaphis erysimi (Kalt.) in rapeseed mustard with botanicals and varietal resistance. Ind. J. Entomol., 74, 289-294 (2012).

Sohi, G.S., A. Singh, B. Singh and M. Beniwal: Effect of sowing date and weather parameters on severity of Alternaria blight on different varieties of Brassica juncea. Int. J. Curr. Microbiol. App. Sci., 9, 3732-3739 (2020).

Yadav, R.B., A. Kumar, A. Kumar and S.K. Verma: Screening of rapeseed-mustard cultivars/lines for resistance against Alternaria blight. Indian J. Sci. Res., 5, 89-91 (2014). 